\title{
Using a Graphic Novel Project to Engage Indigenous Youth in Critical Literacies
}

\author{
ALEXIS BROWN \\ University of Victoria \\ DEBORAH BEGORAY \\ University of Victoria
}

\begin{abstract}
The purpose of this paper is to present the experiences of Indigenous youth when a critical literacies/Indigenous knowledges (IK) approach was used in a graphic novel creation project. We conducted research over a six-week period in two alternative high schools in British Columbia. In this paper, we look primarily at research findings from the Indigenous program. We analyzed classroom observations, the graphic novels, and transcripts of semi-structured interviews according to four principles of critical literacy: understanding power, control, and equity of information; collaboration using multiple perspectives; authentic and multimodal learning; and enacting social change and civic engagement.
\end{abstract}

Keywords

critical literacies, graphic novels, Indigenous adolescents

\section{Introduction}

Canadian colonial education practices have failed to support Indigenous ways of living, learning, and knowing, and have resulted in the marginalization of Indigenous students. In British Columbia, provincial statistics continue to demonstrate that Indigenous adolescents have a lower high-school graduation rate $(64 \%)$ than their nonIndigenous peers (86\%) (British Columbia Ministry of Education, 2016). Previous research indicates that a lack of culturally appropriate curriculum, explicit teaching, and high expectations of Indigenous students has created disengagement and resistance among Indigenous youth (Battiste, 2013; Hare \& Pidgeon, 2011; Pirbhai-Illich, 2010). Despite scholars calling for researchers, educators and curriculum writers to decolonize educational practices, little attention has been given to ways in which classrooms might better address the needs of Indigenous adolescents (Hare \& Pidgeon, 2011). In particular, there is minimal research on language and literacy learning with Indigenous adolescents, which is fundamental to high-school success (Banister \& Begoray, 2013). In order to decolonize language and literacy learning for Indigenous adolescents there is a need to shift educational pedagogy towards knowledge as embedded in place and experiences, and learning models that represent action and sharing (Battiste, 2013) and being civically engaged (Deer, 2013). Battiste argues that "action brings humanity and creativity to life, and doing and being turn life into knowledge and wisdom" (p.114). Therefore, there is a need to focus on engaging and empowering Indigenous youth in culturally appropriate ways (Battiste, 2013; Deer, 2013; Mills et al., 2016). 
Culturally responsive education for Indigenous youth emphasizes the importance of enabling students to use different perspectives, of drawing on student's culture, identity, and communities, and of helping youth to take social action to remedy problems within the school context (see for example, Brayboy \& Castagno, 2009; Deer, 2013). Critical literacies, an educational approach to learning that encourages the critique of dominant ideologies, and the empowerment and enactment of social change, is one promising avenue to support Indigenous students (Luke, 2012; New London Group, 1996; Riley, 2015; Shor, 1999). By taking a critical literacies approach to learning students have opportunities to "see and respond to instances of injustice, expand the identities that they might take up, and participate in communities in service of social change" (Riley, 2015, p. 413) through multimodal forms of expression. As such, the use of multimodal projects that appeal to adolescents, such as the creation of graphic novels (Griffith, 2010) to tell stories of their choice through words and pictures, might make it possible to draw all these purposes together.

In this paper, we describe a research project designed to explore the diverse experiences of 11 high school Indigenous youth when a critical literacies approach was used for a unit that invited students to write and illustrate a graphic novel. This research was part of a larger study examining the processes through which Indigenous and nonIndigenous adolescents develop critical media health literacy (Wharf Higgins \& Begoray, 2012): the ability to work critically with health information within various types of media. The previous studies (Begoray \& Fu, 2015; Begoray, Wharf Higgins, \& Wilmot, 2014; Wilmot, Begoray, \& Banister, 2013) had students writing the storyline, creating storyboards, and developing characters; however, a professional artist was commissioned to illustrate the graphic novels. In this study we instituted a collaborative approach between two different schools, in which the graphic novel would be entirely produced by students. The students in the Indigenous cultural program at one high school were the writers and story developers of the graphic novels, while students from an artsbased high school were tasked with the illustrations.

For the purpose of this article, we focus on the experiences of the Indigenous youth who participated in writing and creating a graphic novel. We hoped that their involvement would serve as a means of empowering them through civic engagement. We further sought to expand on the repertoire of culturally responsive classroom practices. The student-writers selected topics about the impacts of media on their lives, and created storylines to express how youth could make positive social change or seek support for positive change. The graphic novels were designed with a slightly younger audience (1114 years) in mind and the school district published them in hard copy and electronic form. Thus, they were made publicly available as a learning resource for teachers and students.

\section{Researchers' Position Within the Study}

Both researchers are Canadian-born, white, female, academics and educators, and as such acknowledge it is important to explain our relationship to the local territory, Indigenous education, and the process of decolonizing language and literacy learning. The first author (Alexis Brown) lives in the traditional territory of the Secwepemc people, and was previously a high-school teacher within the school district that the project took place. The second author (Deborah Begoray) lives and works on the unceded territory of 
Salish and Coast Salish peoples. She has done extensive research in collaboration with Indigenous students, teachers and Elders. Both researchers are working towards allying themselves with those who are engaged in decolonizing education (Battiste, 2013; Regan, 2010) and in taking action as called upon by the Truth and Reconciliation Commission of Canada (TRC) "developing culturally appropriate curricula" (TRC, 2015, section 10. iii p.149). In working towards being allies and in decolonizing education, it is important that we acknowledge our experiences as non-Indigenous, and one of privilege located within a colonial system. We believe that the importance of personal truth-telling and the making of space for IK, cultures, and experiences are the responsibility of everyone involved in decolonizing education (Battiste, 2013; Regan, 2010).

\section{Theoretical Frameworks}

In this study, we have applied a sociocultural framework (Gee, 1992; Vygotsky, 1989), emphasizing both collaborative work and the culture of Indigenous ways of learning and knowing (Battiste, 2013; Brayboy \& Maughan, 2009). In particular, Indigenous ways of learning and knowing include knowledge as rooted in location and experience (Barnhardt \& Kawagley, 2005; Battiste, 2013; 2002; Brayboy \& Maughan, 2009; Hare, 2012). A sociocultural framework identifies literacy learning and practices as socially constructed through collaboration and experiences, and embedded in cultural, political and historical contexts.

Drawing on sociocultural theory, Gee (1992) used the term Discourses with a capital "D" as a way to name literacy practices found in different lifeworlds, and argues that Discourses are a "distinctive and integrated way of thinking, acting, interacting, talking, and valuing connected with a particular social identity or role, with its own unique history, and often with its own distinctive "props"” (p. 33). IK systems and lifeworlds connect to sociocultural theory in that Indigenous learning and ways of knowing are connected to place, embedded in language, stories, and experiences, and tied to the community (Barnhardt \& Kawagley, 2005; Battiste, 2013; 2002; Brayboy \& Maughan, 2009). Scholars working in the field of IK and ways of learning (Barnhardt \& Kawagley, 2005; Brayboy \& Maughan, 2009; Battiste, 2002; 2013; Kanu, 2011) have identified distinct features of Indigenous ways of learning: learning as holistic (mental, physical, emotional, spiritual), learning as a lifelong process, and learning as experiential (observing and doing) and authentic.

We also used a critical literacies (Freire, 1970; Luke, 2012; Shor, 1999) framework for this study. Shor says that:

[C]ritical literacy is language use that questions the social construction of the self. When we are critically literate, we examine our ongoing development, to reveal the subjective positions from which we make sense of the world and act in it. All of us grow up and live in local cultures set in global contexts where multiple discourses shape us. (p. 2)

Shor acknowledges the subjective or personal experiences in which individuals live and make sense of the world. As such, a critical literacies approach to education is "a way to talk and think about students as knowledge-holders and producers, and a way to talk and think about teachers' pedagogical practices" (Avila \& Pandya, 2012, p.1). It also 
represents a political and historical orientation and attitude (Luke, 2012; Shor, 1999) towards literacy, learning and education.

Shor's (1999) definition is also congruent with concepts of IK. Brayboy and Maughan (2009) explain that:

Indigenous knowledges are rooted in the lived experiences of people; these experiences highlight the philosophies, beliefs, values, and educational processes of entire communities. Indigenous peoples come to know things by living their lives and adding to a set of cumulative experiences that serve as guideposts for both individual and communities over time. In other words, individuals live and enact their knowledge and, in the process, engage further in the process of coming to be - of forming a way of engaging others and the world. (p. 3)

Brayboy and Maughan's understanding of IK emphasizes the importance of the social construction of the self through lived experiences, in which those experiences guide the individual in how they make sense of who they are and how they interact in the world. Shor's definition of critical literacy also emphasizes the importance of the social construction of the self through examining individual development and revealing the local cultures and discourse, or experiences, which shape who we are.

Critical literacies highlights four major principles that include examining issues relating to power, control, and equity of information; engaging in authentic learning; using collaborative and multiple perspectives to make meaning; and enacting social change through civic engagement (see for example, Alvermann, 2009; Freire, 1970; Janks, 2014; Luke, 2012; New London Group, 1996; Riley, 2015; Shor, 1999; Street, 2003). We chose the four highlighted principles to categorize our findings.

\section{Review of the Literature}

Among both Indigenous and non-Indigenous scholars in education, there has been a call to decolonize education (Battiste, 2013; Murray-Orr et al., 2013; St. Denis, 2007). Decolonizing includes the recognition and acknowledgement of the atrocious past treatment of Indigenous peoples such as the use of residential schools, treaties and government policies meant to force assimilation. Further, decolonization outcomes include "the need for systemic awareness of everyone and the reconciliation and healing in educational systems" (Battiste, 2013, p. 107). Therefore, a shift in educational pedagogies needs to occur from a predominant focus on Western approaches in order to make space for IK, ways of learning, and self-determination. This "two-eyed seeing" encourages an intersection of approaches (Murray-Orr et al., 2013) which helps to create a more culturally responsive curriculum (Brayboy \& Castango, 2009). In particular, critical literacies approaches include the significance of action for civic engagement, which aligns with decolonizing education and IK as action for humanity becomes knowledge and wisdom (Battiste, 2013; Deer, 2013). 


\section{IK and Literacy Learning}

Scholars and researchers in the field of IK and ways of learning (Battiste, 2013; Hare, 2012) remind us that IK are a complex system that is embedded in local places and as such there are differences from one territory and community to another. There are more than 600 First Nations in Canada and each one has its unique customs, language, social structure, and history (Ball, 2004). However, as mentioned above, many scholars (e.g., Battiste, 2013; Brayboy \& Maughan, 2009; Hare \& Pidgeon, 2011; Murray-Orr et al., 2013) agree that there are some overarching values and beliefs in IK that include the significance of community and community members, collaboration, and dialogue, as well as a belief in importance of the land, wisdom of Elders, and spirituality.

Research with Indigenous youth engaging with IK in the classroom shows that these youth are more engaged and motivated, and feel more positive about themselves and their cultures (Brayboy \& Castagno, 2009; Hare, 2012; Kanu, 2011). For example, Kanu's research with self-identified Aboriginal youth in Manitoba sought the voices of the youth in order to investigate the influence of culture on learning and to identify aspects of cultural socialization that students utilized to respond to curriculum and learning in the high school classroom. She found that students showed a great level of familiarity with cultural practices and knowledge structures within the community. As well, students demonstrated comfort, authority and knowledge when asked about cultural practices and learning structures such as the use of stories, observation, the importance of community support, and experiential learning. Further, students were able to identify how they might mediate their in-school learning through cultural practices such as receiving more oral instruction and working in groups to support one another. Students maintained that the 'self' emerges from cultural and communal situations, explaining that they work better in collaborative and cooperative group learning situations. The students also indicated preferences to learning through observing and doing, stories, community, and visual modalities.

Similarly, Hare's (2012) study of five different Aboriginal Head Start On Reserve programmes in western Canada sought to understand how early childhood literacy programs can be enhanced with IK. Although this study was not conducted with adolescents, the findings still reveal the significance of literacy learning in relation to IK through the use of oral traditions, land-based experiences, and ceremonial practices. Many of the children's families recognized the significance of IK and the links to enhancing school literacy skills, particularly through the use of storytelling (Hare, 2012). Other forms of literacy acknowledged were land-based experiences like picking berries, fishing, hunting, making baskets, dancing, singing, and participation in traditional ceremonies. Hare's (2012) study relates to Kanu's (2011) in that IK and ways of learning for Indigenous youth should include the use of collaboration, stories, community, visuals, and authentic learning through participation.

\section{Critical Literacies and Culturally Responsive Education}

Many facets of critical literacies, such as authentic and collaborative learning, and the use of multimodalities and multiliteracies, are recognized by scholars as culturally appropriate and culturally responsive education for Indigenous students (Hare, 2011; 2012; Mills et al., 2016; Patrick, Budach, \& Muckpaloo, 2013; Stanton \& Sutton, 2012). Drawing on concepts of community-based literacy practices, along with multiliteracies 
and critical literacies, Stanton and Sutton's participatory action research with Indigenous high-school students in the U.S. examined how students were able to draw on oral and visual literacies to enhance written literacy skills. Stanton and Sutton argued that culturally responsive education includes uses of place-based literacies, and that uses of literacies other than writing can increase motivation and engagement for youth in school. The researchers worked with students to produce a photovoice project as well as conducting interviews with Elders around important local community issues. The researchers found that through this project students could explore and respond to community challenges such as the limited access to transportation and healthy food on reserve; identify themes connected with dignity and sovereignty; act in response to information such as the need to adopt healthy behaviours; connect to cultural and civic forms of literacy such as discussing boycotting the local store, developing a community garden, and reintroducing traditional foods; collaborate and connect to their local community by consulting with parents, Elders, and council; and share their findings with community leaders and Elders. Stanton and Sutton also found that the projects "helped students view literacy development as a holistic, collaborative, and powerful process" ( $\mathrm{p}$. 83).

In another study focused on multimodal projects, Mills et al. (2016) explored culturally inclusive approaches to literacy with Indigenous youth. They argued that current approaches to literacy pedagogy must follow IK in a time of increased digital and technological communications. The students in their study were asked to retell an Indigenous Dreamtime story from South East Queensland using multimodal forms and specific digital technologies. Findings from the study included the significance of transgenerational knowledge, multimodal forms of knowledge, placed or territorial knowledge, and collective knowledge. Mills et al. (2016) advocate for more research on culturally responsive education for Indigenous youth, particularly with regards to accessing powerful language and the use of public platforms in situating students in local and global contexts.

\section{Graphic Novels and Adolescent Literacy Practices}

A graphic novel is a book-length, fiction or nonfiction story produced in the style of a comic book (Danzak, 2011). Graphic novels are popular with adolescents (Griffith, 2010; Smetana et al., 2009) and have proven worthy as quality literature (Pantaleo, 2015; Seelow, 2010). Some examples are Maus (Speigelman, 1980) which deals with the Holocaust; Fun Home (Bechdel, 2007) on sexuality; and Red (Yahgulanaas, 2009) which concerns the consequences of violence and revenge in a Haida community. Red was written and illustrated by an Indigenous author and features a Haida tale told with Japanese-influenced manga style illustrations.

Graphic novels combine print and visuals in ways that engage youth in the reading experience (Begoray \& Fu, 2015; Wilmot, Begoray, \& Banister, 2013). Schieble (2014) comments on the importance of "fostering a complex and structural understanding of racism and power while simultaneously building students' critical thinking and interpretive skills" (p. 47) through critical reading of graphic novels. Such construction of critical thinking and interpretation is possible by looking closely at both images and print in a graphic novel. For example, Schieble suggests examining the depiction of characters 
in American Born Chinese (Yang, 2006) to notice stereotypical clothing and animal features to determine the author's message about racism against Chinese immigrants.

Creating graphic novels with youth is a further step that moves students "beyond passive consumers of texts to active producers of knowledge" (Seelow, 2010, p. 57) and offers a variety of literacies to engage and motivate adolescents (Stanton \& Sutton, 2012). Such compositions can also engage students in critical literacy; that is, in the consideration of how to represent power issues (Bitz, 2006). The creation of socioculturally shaped, multimodal artifacts (Serafini, 2015) offer students, especially those from non-dominant cultures, a chance to explore their identity and life experiences. Such a classroom opportunity is a culturally responsive literacy experience (Mills et al., 2016). Indigenous students' ability to learn is strongly tied to how harmoniously their cultural identities match that which they are to learn or the pedagogical practices, such as the use of IK, used in the learning environment (Pirbhai-Illich, 2010).

\section{Methodology}

Using a qualitative case study approach (Yin, 2014), we conducted a six-week collaborative graphic novel project with Indigenous students $(n=11)$ ranging in Grades 10 to 12 from an Indigenous cultural school program in one high school; and with students $(\mathrm{n}=16)$ in Grades 10 to 12 who identified as both Indigenous and non-Indigenous in an arts-based school program at a different high school. The focus of this article is on the students in the Indigenous cultural school program. The student participants in the study all identified as Indigenous and came from different communities within British Columbia, Saskatchewan, and Manitoba.

This research project took place on the unceded land of the Tk'emlups te Secwepemc and the traditional territory of the Secwepemc people. The Indigenous cultural program is located within an urban alternative high school where students who self-identify as Indigenous may choose a school program that includes access to cultural enhancing activities such as Elders' circles, drum group, art, Lahal tournaments, ${ }^{1}$ outdoor retreats, and canoeing. We were able to gain access to the school because Alexis (first author) had taught at the alternative high school and was therefore a former colleague of the teacher involved. We asked: How might creating graphic novels help to reveal Indigenous youth's critical perceptions of power in the media and its influence on their well-being? How might a critical literacies graphic novel project serve as a culturally responsive classroom practice to empower Indigenous youth?

Students in the Indigenous cultural program wrote the storylines for the graphic novels, and students in the arts-based school illustrated the graphic novels with input from the writers. Although Deborah's (second author) previous research on graphic novel creation had utilized a professional artist, we wanted to provide an opportunity for students from different high schools to collaborate in order to have graphic novels that were entirely done by students. As well, due to time constraints within each program, and the large undertaking of the project, having the students share the development of the novels was more feasible for the classroom teachers and their students. The students in

${ }^{1}$ Lahal is a traditional Secwepemc guessing game that includes teams of six people, and the use of 11-13 sticks and 4 bones. Lahal is played on special occasions, celebrations and gatherings. 
the Indigenous cultural program were chosen to be the writers as it fit within the classroom teacher's goals of wanting to engage her students in meaningful writing practices. The teacher in the arts-based program wanted to provide her media-arts students with an authentic opportunity to produce a product within a collaborative "client-like" relationship.

Students from both the high schools did not know each other, and due to the different schedules and proximity of the schools from one another, did not meet face to face until the graphic novel launch party to celebrate their publications. As such, Alexis moved between the two schools to facilitate dialogue between the writers and artists. The writers and artists communicated through file folders and post-it notes that contained the storylines, developing images and commentary. The writers were able to make comments and ask for illustration revisions from the artists. Along with the classroom teacher, Alexis also provided instruction on critical literacies, media, and health. The classroom lessons included critical literacies instruction and discussions on power, knowledge, and equity of information, particularly through media. For example, students were asked to view commercials, music videos, and magazine images. Whole class discussions around the media images or videos occurred when students were asked to consider the following: What is the purpose of this media message? Who produced it? Who is the intended audience and how do you know that? Who might benefit from this message and who might be harmed? What strategies were used to grab your attention? What information was given and what was left out? What values are evident in the messages? Do they represent you? Is this information trustworthy? Why do you think so?

The students in the Indigenous cultural program also had instruction on Indigenous identities, stereotypes, and the media from a member of their community, which included further discussions about power, knowledge, and equity of information. Students were asked to brainstorm what their Indigenous cultural values and identities were (Fig. 1) and contrast their values with the values and identities of the mainstream media (Fig. 2). 


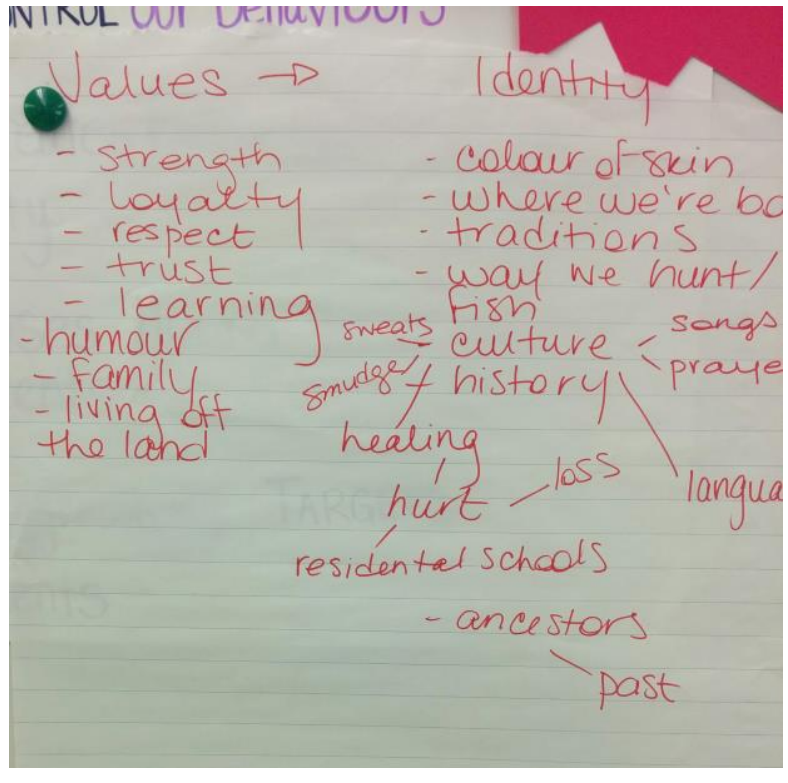

Figure 1. Brainstorm of Indigenous cultural values

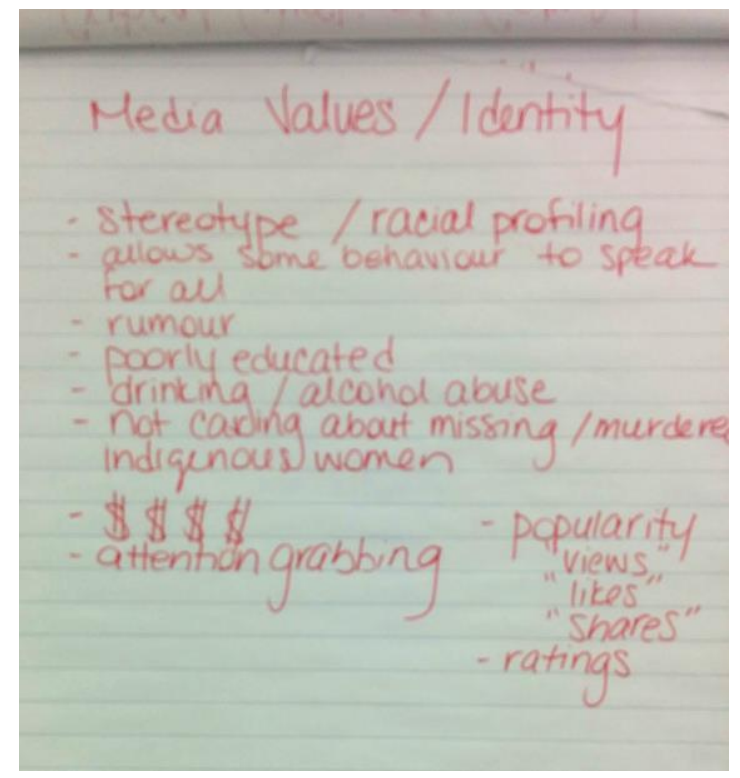

Figure 2. Brainstorm of media values

Other approaches to involving students with critical literacies were achieved through the writing and designing of the novels, choosing topics that were important and relevant to their lives, opportunity to collaborate within their own classroom and between the two schools, and having their novels printed and presented at a graphic novel launch party. Writers and artists met each other and unveiled their work to members of the school district, the press, and the general public including local band members.

Data was collected through classroom observations, examination of youthproduced graphic novels and semi-structured interviews. Nvivo software was used to store data and support analysis (Yin, 2014). The data was transcribed and coded using the four principles of critical literacies drawn from the literature: understanding power, control, and equity of information; collaboration using multiple perspectives; authentic and multimodal learning; and enacting social change and civic engagement (Freire, 1970; Janks, 2014; Luke, 2012; New London Group, 1996; Riley, 2015; Shor, 1999). The four principles of critical literacies are used as categories below (Corbin \& Strauss, 1990; Yin, 2014).

\section{Findings}

Under each critical literacy principle, we discuss students' responses regarding the creation of their graphic novels to reveal critical perceptions of power in the media and its influence on their well-being. All names used in the findings are pseudonyms.

\section{Understanding Power, Control, and Equity of Information}

During the early stages of the project, the students were engaged in discussions on power, control, and equity of information in the media. Students were asked to look at various types of media and to critically analyze the message and purpose of those sources; and consider the topics of Indigenous identity, media, and stereotypes. As well, 
Alexis shared a graphic novel (No Sale, Skèlèp!) also written by Indigenous adolescents (Deana Asham, Alexander Corbett, Samantha Douglas, Spencer Rennie, Paige Rivers, and Maria Thomas, 2014) to further discussions on media related messages and provide an example for considering their own graphic novel storylines. By drawing on these lessons, the students were able to express their understanding of power and control of information in the media through examples of cultural identities that were present in their own graphic novels. In Figures 1 and 2 above, for example, students show that they understand the differences between Indigenous and media values, contrasting for instance how Indigenous ways of knowing values family and how dominant media messages values money. When students were asked about why they chose a particular topic to write about, their understanding of media stereotypes is shown once again. One student, Wes, said:

Well, no one else in the class was doing this kind of stuff and we thought it would be a great idea to make a novel about it, just sort of like the other one you showed us, but [with] Aboriginal people [...] how the stereotypes are on Aboriginal people and how not everyone is like that.

Wes recognized that Indigenous peoples are often missing from media, or if present, they are often misrepresented by the media. His group's graphic novel addressed stereotypes and racism that Indigenous teenagers face such as being "drunks" or "violent" (Friedel, 2010). They included Indigenous voices in their graphic novel to address the issue of Indigenous voice and identity being usually absent in the media. During the classes where the students were working on their storylines, Wes and a group of his friends shared previous experiences they had had regarding stereotyping and racism, including being asked to remove their bags when in a convenience store while their non-Indigenous peers were not asked; or being overtly followed around in a department store when shopping for clothes. These types of experiences that include stereotyping or racism are not uncommon for Indigenous teenagers to face (Friedel, 2010; Hare \& Pidgeon, 2011), and Wes and his peers wanted to change the narrative to represent the resilience of Indigenous peoples and the importance they place on community and family values.

Another student writer, Hugh, commented on his topic choice:

Because I've had a lot of close friends lose their moms and such over the past 15 years, and like I've really got close with many of them [...] it just seems like the police department in general doesn't really put that much effort into it [...] because if you go on Facebook or search up First Nations Aboriginal people I guarantee you within the first 200 things you find on it, one of them it's going to say a "drunk native," and not every native goes out and drinks and all that. Then whenever someone goes missing they just probably think it's oh, it's probably reasons of drinking as well.

Hugh is referring to the issue of missing and murdered Indigenous women, the topic of the novel he co-authored. His personal experiences with the topic, along with his belief that media portrays Aboriginal peoples as "drunk natives" demonstrates his understanding of power, control, and equity of information in the media. Hugh's decision 
to write on the topic of missing and murdered Indigenous women displays a sense of cultural identity in that he expresses the misrepresentations of his culture and the need to contribute to an important conversation happening between Indigenous communities and the government.

Hugh's co-author, Randy, responded to the same question by saying that:

It makes them [the people who will read the novel] more aware that not everybody's caring for everybody and a lot of people are just worried about [themselves], not so worried about the Indigenous women or any other Indigenous people that are going through hard times. Knowing that they don't have much on their side to help them out.

When asked why he and his partner chose the topic of missing and murdered Indigenous women, Randy poignantly stated that "not everybody's caring for everybody," a core understanding of the importance of community and the need to look out for each other. Randy and Hugh both articulate the opinion that although Indigenous people have been largely left out of mainstream media, they see society as a larger community in which everyone should be involved and cared for. Embedded in these responses is the importance of community, an integral aspect of IK (Brayboy \& Maughan, 2009).

\section{Collaborating Using Multiple Perspectives}

All the students in the Indigenous program take part in group activities such as Elders' circles, team sports, drum group, and other off-site group activities. However they are expected to learn on their own through individualized and self-paced programming where they work individually in their core subjects such as English language arts. Their teacher, Ms. Wilson, admitted that she was unsure how the students would react to group lessons and collaborative work in the graphic novel project, especially when it came to sharing their work with others. During the interview at the end of the project Ms. Wilson said:

[I] t's interesting because initially I thought that they might not like that [working with others on a project]. Many of them are really private and they are quite shy and anxious and it was just interesting, right, to share their work. I mean sometimes I have to really remind them "you know that only I read this right?" because some of them just have such a hard time putting stuff on paper. So it's like that was a big leap for them to take, to not only share but to share it with complete [strangers]; they didn't have any idea where it's going. So it was exciting to hear that they liked it.

In their interviews, many of the students confirmed Ms. Wilson's comments. They said that collaboration was engaging and motivating, and allowed them to share knowledge. When students were asked what they thought about the project and working with another group of students from a different school, the responses were overwhelmingly positive and shed light on the importance of sharing and building knowledge. For example, one student said: 
It shows me more, it's getting me interested in knowing that there is somebody else that is helping me and that I don't even know them and they are helping me with a project that I'm doing with my school and it's really interesting too. (Randy)

Though a few students noted that they liked sharing the workload of the project in terms of not having to do all the writing and drawing, other students mentioned that they enjoyed working with group members because they could support each other and learn from one another:

[...] the people I was working with, they helped me through it and then I helped them and we just brought everything that we could basically think of into it [writing the storyline]. (Neil)

Hugh expressed similar sentiments, stating that:

It's great working with my partner on this and going around looking at other people's projects, it seems like they were really interested in their topics. (Hugh)

Sharing knowledge and collaboration through talking and dialogue is part of Indigenous pedagogies and ways of knowing (Battiste, 2002; 2013; Brayboy \& Maughan, 2009). Further, as previous research (Alvermann, 2009; Kanu, 2011) with adolescents demonstrates, collaboration is engaging and motivating for learning. The Indigenous youth in this study straddle multiple worlds that include Indigenous, Western, and adolescent worldviews. As such, adolescents want to build and share information in collaborative ways (Alvermann, 2009; Kanu, 2011), which align with Indigenous ways of learning and knowing.

\section{Authentic and Multi-modal Learning}

For authentic learning to occur, learning must be relevant and meaningful, and include multiple voices, experiences, and individual and collective backgrounds (Freire, 1970; Gee, 1991; New London Group, 1996; Shor, 1999). Further, authentic learning includes expression of thoughts and ideas in multi-modal and multiliterate ways (Alvermann, 2009; New London Group, 1996; Street, 2003). Students in this study made strong connections to concepts of authentic and multi-modal learning in that they expressed the importance of the topics they chose, the need to voice and share knowledge of their topics in mainstream media, and the use of a graphic novel as a communication platform. Students drew on issues that they wanted to address with regards to their community such as the need for ongoing investigations into murdered and missing Indigenous women, understanding residential schools, and media-perpetuated stereotypes of "the drunken native." One student, when asked which parts of the novel were most meaningful, said:

Meaningful wise it's like residential school has put a toll on my family, my grandmother and so on have been through it and people that I even know throughout my mom's social work career or just meeting them, I've heard many 
stories so it just brought my mind to a conclusion that this would be the thing I wanted to work on because it's pretty important. (Neil)

Students also showed increased investment and interest once they started to see their stories turn into graphic novels. Referring to the abilities of the high-school art students who would be illustrating their work one writer commented:

It's pretty cool actually knowing that there are people this talented to do work like this at such a young age. (Mika)

Another student commented that:

I can say that the people [student artists] who actually turned the writing and the characters we had at first into an actual graphic novel as I can look right now, like I wouldn't have this any better than it is already [...] This is a great opportunity to get together with people and just talk about one subject, like most schools, they don't really show this, or do this stuff with the students; they don't interact with the students as much as like this. (Hugh)

The use of authentic and multimodal learning showed increased engagement and investment in learning, aligning with research findings from Stanton and Sutton (2012), who also found that authentic learning through a community project engaged and motivated Indigenous students. Authentic and multimodal learning is also in alignment with Indigenous ways of learning as learning is meant to be relevant and experiential (D'warte, 2014; Murray-Orr et al., 2013; Patrick, Budach, \& Muckpaloo, 2013; Stanton \& Sutton, 2012). Through selecting topics that were of relevance and importance to themselves and their community, as well as creating a graphic novel in which they determined the look and layout of their story, students were able to experience, demonstrate, and share their understanding and learning.

\section{Enacting Social Change and Civic Engagement}

Through both the production of the graphic novels, which were designed to be used in future classrooms, and the development of the graphic novel characters and storylines, students demonstrated civic engagement and ways to enact social change. Students expressed ideas around empowerment and sharing knowledge in order to make change. As Alfred et al. (2007) remind us about fostering greater engagement: "Indigenous youth require opportunities to engage in activities that privilege Indigenous histories and experiences, and they stress the need for these activities to be accessible to Indigenous communities as well as formal education institutions" (p. 16). When asked about their favourite parts of their graphic novels, many of the students said they liked how their main characters became engaged. Examples include: 


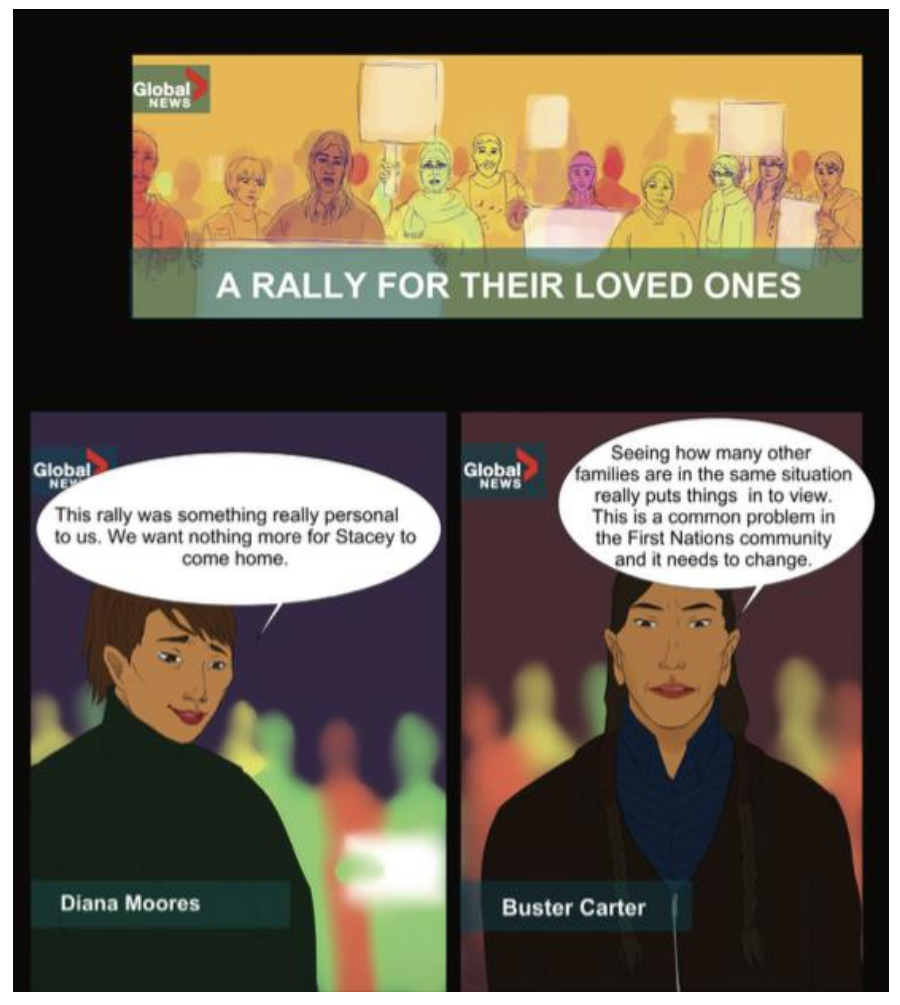

Figure 3. The characters organize a rally for loved ones in Randy's graphic novel

[w] hen one of the characters decides to take [actions] in his own hands to do what he feels is right to do and he does a protest and gets people together that are in the same situation or kind of the same situation. (Randy, in reference to Fig. 3)

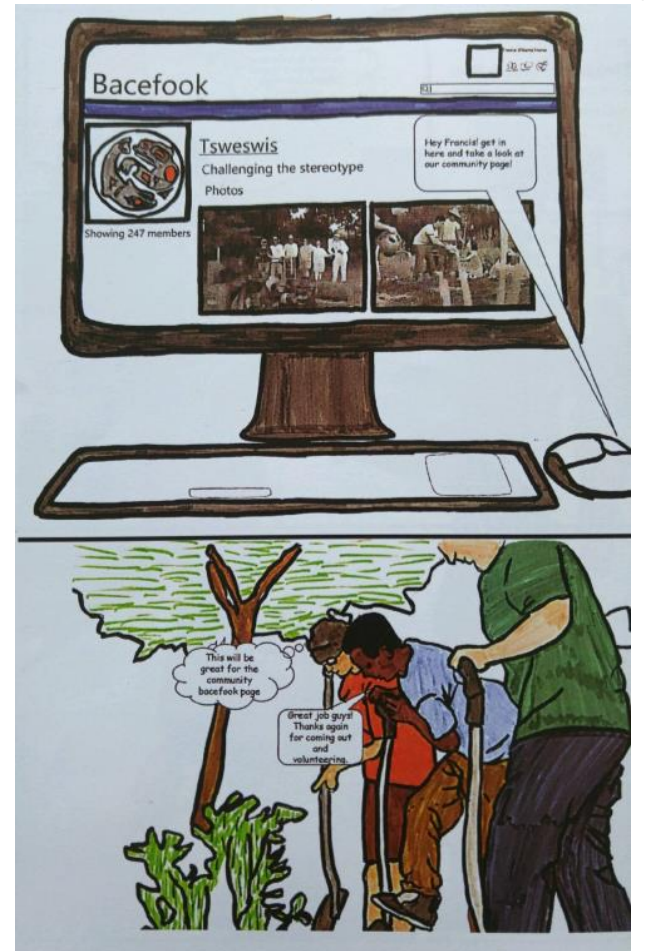

Figure 4. The characters create a Facebook page and take action in Wes' graphic novel 
The part where they made the [Facebook] page to show that not all Aboriginal people are what the media portrays them as. Like there are some out there like that but they have the reasons for them to be who they are, but then there are others [...] that aren't [...] and they want to prove it to people. (Wes, referring to Fig. 4)

When students were asked what they thought about their graphic novels being used in future classrooms as a teaching tool they responded with hope that their messages would help others:

I don't know if this is going to be helpful or not, but I hope it is because people need to know that there's actually quite a lot of people in this world today dealing with these problems [...] and that's there's actually places where you can go to seek help [...] and you really shouldn't feel alone about it [...] or ashamed of it because these problems weren't caused by the person themselves. (Mika)

Another student articulated his desire that others would read his novel in order to open a discussion on the missing parts of his history:

I'm hoping that they will keep reading [the graphic novel] and they will figure out what [residential schools] has done to traditions and what it has done to the Bands and Nations and what media portrayed about it, and that [schools and media] didn't bring it to attention as early as they should have. (Neil)

Neil's words above also convey the importance he places on empathy. Neil hoped that the story would allow others to understand what residential schools have done to Aboriginal cultures, while another student expresses the need for people to truly care and understand that some people need help:

We were thinking about what was going on right now and what would be important to get the word out, too, so that people know about it [...] and just to help out [...] There are people out there that don't have as much help as other people [...] and they would just like more help [...] Those people who care a lot wish everybody could understand or care (Randy)

Students recognized that Indigenous voices have largely been left out of media and mainstream conversations, and articulated the idea that they want other people to know and understand their experiences, to express more empathy for those who are struggling, and to let those who are struggling know they are not alone. Further, students developed their own voices and pathways to change by embedding positive action through civic engagement within their novels.

\section{Discussion and Implications}

Students understood the nature of power and the misrepresentations of their cultures in the media. Embedded within their expressions of cultural identity and misrepresentations was the significance of sharing knowledge and recognizing the power of their own voices. Many of the students expressed the importance of and need to share 
both personal and community experiences, and to "re-present" (Madden, Higgins, \& Korteweg, 2013) their cultural identities. The students valued learning from each other, and being part of a wider public conversation. From these findings, educators might consider ways to involve community members as part of the value of sharing knowledge, and create opportunities for students to share their own knowledge with each other, and within the broader community.

Students also expressed the value they placed on having a wider audience, such as other students, teachers, and district administrators, so their voices could be heard. At the beginning of the project the students were informed that their novels were to be written as a teaching resource for younger adolescents, and would be made publicly available in the school district. When the students were asked how they felt about collaborating with others and producing novels for future students to read and learn, their responses were filled full of expressions of both happiness and gratitude in that "somebody cares" about what they had to say. Students also expressed that they hoped what they had to say would help other people understand more about a particular situation, or let others know that they were not alone in their struggles. Again, educators must be aware of the importance of sharing knowledge, but also in providing authentic opportunities for students to share their learning beyond a classroom or school environment.

Increased student interest and investment in the project was especially linked with how the students felt about the topics they were writing, the collaborative aspect of the project, and use of visuals as a means to translate their stories. This finding is in alignment with other research (Alvermann, 2009; Wilmot, Begoray, \& Banister, 2013; Fecho, Coombs, \& McAuley, 2012; Hare, 2012; Kanu, 2011) on the importance of collaboration for teenagers, and especially Indigenous youth, who value working and learning with and from others. In order for educators to be more inclusive generally, and culturally responsive specifically, it is important that learning is collaborative, authentic, and multimodal in order for students to express their understandings in meaningful ways.

\section{Conclusion}

We demonstrate through this research that a collaborative, critical literacies project on creating graphic novels resulted in these Indigenous students' increased engagement, motivation and investment in classroom work. As well the students in the study made connections to the importance of sharing knowledge, cultural identity and locating cultural misrepresentations. Finally, through the use of the graphic novel format and using Indigenous ways of knowing in a classroom, students were able to find a voice on critical media health literacy topics affecting them and their communities. Battiste (2013) argues that

[a]s educators and teachers begin to confront new schemes of Indigenous knowledge and learning [...] they will need to identify new processes. These include raising the collective voice of Indigenous peoples, exposing the injustices in our colonial history, deconstructing the past by critically examining the social, political, economic, and emotional reasons for silencing Aboriginal voices [...] (p. 167) 
While the education system still has much work to do in order to appropriately address and include IK and ways of learning, we hope that our research using a critical literacies approach contributes to the ongoing conversation on how educators can help raise the collective voice of Indigenous peoples. This process can start with increasing the civic engagement of Indigenous adolescents. As previously stated, we are "advocating for research with/by Indigenous youth that brings youth together and increases their stock of knowledge, tools and methods as well as gathers strength and resolve" (Korteweg \& Bissell, 2015, p. 15) to help resolve Indigenous issues in Canada. We see our work as one way to begin to address issues of reconciliation.

\section{Acknowledgements}

We acknowledge the generous cooperation of students, teachers and Elders who participated in this project. We further acknowledge the support of CIHR whose funding made this research possible.

\section{References}

Alfred, T., Pitawanakwat, B., \& Price, J. (2007). The meaning of political participation for Indigenous youth: Charting the course for youth civic and political participation. Ottawa, ON: Canadian Policy Research Network. Retrieved from http://www.cprn.org/documents/48503_EN.pdf

Alvermann, D. (2009). Sociocultural constructions of adolescence and young people's literacies. In L. Christenbury, R. Bomer, \& P. Smagorinsky (Eds.), Handbook of adolescent literacy research (pp. 14-28). New York, NY: Guilford Press.

Asham, D., Corbett, A., Douglas, S., Rennie, S., Rivers, P., \& Thomas, M. (Illustrated by C. Ryan). (2014). No Sale, Skèlèp! Victoria, BC: Begoray, Wharf Higgins, Banister and Marshall. Retrieved from http://gvpl.ca/assets/PDF/Audiences/Teens/nosalefull-comic.pdf

Avila, J., \& Pandya, J. (2012). This issue. Theory Into Practice, 51(1), 1-3.

Ball, J. (2004). As if Indigenous knowledge and communities mattered: Transformative education in First Nations communities in Canada. American Indian Quarterly, 28(3/4), 454-479.

Banister, E., \& Begoray, D. (2013). Using Indigenous research practices to transform Indigenous literacy education: A Canadian study. Journal of American Indian Education, 51(1), 65-80.

Barnhardt, R., \& Kawagley, A. (2005). Indigenous knowledge systems and Alaska Native ways of knowing. Anthropology \& Education Quaterly, 36(1), 8-23.

Battiste, M. (2002). Indigenous knowledge and pedagogy in First Nations education: A literature review with recommendations. Ottawa, ON: Indian and Northern Affairs Canada.

Battiste, M. (2013). Decolonizing education: Nourishing the learning spirit. Saskatoon, SK: Purich Publishing Limited.

Bechdel, A (2007). Fun home: A family tragicomic. New York, NY: Mariner Books.

Begoray, D., \& Fu, H. (2015). Reading Chasing Adland: Middle years' students in pursuit of critical media health literacy. In D. Begoray \& E. Banister (Eds.) (pp. 25-44). Adolescent health literacy and learning. New York, NY: Nova Science Publishers Inc. 
Begoray, D., Wharf Higgins, J., \& Wilmot, R. (2014). Chasing Adland: Teaching critical media health literacy. English Practice, 56(1), 55-61

Bitz, M. (2006). The art of democracy/democracy as Art: Creative learning in afterschool Comic book clubs. Afterschool Matters 7, 2.

Brayboy, B., \& Castagno, A. (2009). Self-determination through self-education: Culturally responsive schooling for Indigenous students in the USA. Teaching Education, 20(1), 31-53.

Brayboy, B., \& Maughan, E. (2009). Indigenous knowledges and the story of the bean. Harvard Educational Review, 79(1), 1.

British Columbia Ministry of Education (2016). Aboriginal Report 2011/12 - 2015/16: How Are We Doing? Retrieved from http://www.bced.gov.bc.ca/reports/pdfs/ab_hawd/Public.pdf

Corbin, J., \& Strauss, A. (1990). Grounded theory research: Procedures, canons, and evaluative criteria. Qualitative Sociology, 13(1), $3-21$.

Danzak, R. L. (2011). Defining identities through multiliteracies: ELL teens narrate their immigration experiences as graphic stories. Journal of Adolescent and Adult Literacy, 55, 187-196.

Deer, F. (2013). Integrating aboriginal perspectives in education: Perceptions of preservice teachers. Canadian Journal of Education, 36(2), 175-211.

D’warte, J. (2014). Exploring linguistic repertoires: Multiple language use and multimodal literacy activity in five classrooms. The Australian Journal of Language and Literacy, 37(1), 21-30.

Fecho, B., Coombs, D., \& McAuley, S. (2012). Reclaiming literacy classrooms through critical dialogue. Journal of Adolescent \& Adult Literacy, 55(6), 476-482.

Freire, P. (1970). Pedagogy of the oppressed. New York, NY: Continuum.

Friedel, T. (2010). The more things change, the more they stay the same: The challenge of identity for native students in Canada. Cultural and Pedagogical Inquiry, 1(2), 22-45.

Gee, J. (1992). Socio-cultural approaches to literacy (literacies). Annual Review of Applied Linguistics, 12, 31-48.

Griffith, P. (2010). Graphic novels in the secondary classroom and school libraries. Journal of Adolescent \& Adult Literacy, 54(3), 181-189.

Hare, J. (2012). 'They tell a story and there's meaning behind that story': Indigenous knowledge and young indigenous children's literacy learning. Journal of Early Childhood Literacy, 12(4), 389-414.

Hare, J., \& Pidgeon, M. (2011). The way of the warrior: Indigenous youth navigating the challenges of schooling. Canadian Journal of Education, 34(2), 93.

Janks, H. (2014). Critical literacy's ongoing importance for education. Journal of Adolescent \& Adult Literacy, 57(5), 349-356.

Kanu, Y. (2011). Integrating Aboriginal perspectives into the school curriculum: Purposes, possibilities, and challenges. Toronto, ON: University of Toronto Press.

Korteweg, L., \& Bissell, A. (2015).The complexities of researching youth civic engagement in Canada with/by Indigenous youth: Settler-colonial challenges for Tikkun Olam-Pedagogies of repair and reconciliation. Citizenship Education Research Journal, 5(1), 14-23. 
Luke, A. (2012). Critical literacy: Foundational notes. Theory Into Practice, 51(1), 4-11.

Madden, B., Higgins, M., \& Korteweg, L. (2013). "Role models can't just be on posters": $\mathrm{Re} / \mathrm{membering}$ barriers to indigenous community engagement. Canadian Journal of Education, 36(2), 212.

Mills, K., Davis-Warra, J., Sewell, M., \& Anderson, M. (2016). Indigenous ways with literacies: Transgenerational, multimodal, placed, and collective. Language and Education, 30(1), 1-21.

Murray-Orr, A., Meader, J., Munroe, E., Borden, L., \& Toney, D. (2013). Decolonizing Aboriginal education in the $21^{\text {st }}$ century. McGill Journal of Education, 48(2), 317-337.

New London Group. (1996). A pedagogy of multiliteracies: Designing social futures. Harvard Educational Review, 66(1), 60-92.

Pantaleo, S. (2015). Language, literacy and visual texts. English Education, 49(2), $113-$ 129.

Patrick, D., Budach, G., \& Muckpaloo, I. (2013). Multiliteracies and family language policy in an urban Inuit community. Language Policy, 12(1), 47-62.

Pirbhai-Illich, F. (2010). Aboriginal students engaging and struggling with critical multiliteracies. Journal of Adolescent \& Adult Literacy, 54(4), 257-266.

Regan, P. (2010). Unsettling the settler within: Indian Residential Schools, truth telling, and reconciliation in Canada. Vancouver, BC: UBC Press.

Riley, K. (2015). Enacting critical literacy in English classrooms. Journal of Adolescent \& Adult Literacy, 58(5), 417-425.

Schieble, M. (2014). Reading images in American Born Chinese through critical visual literacy. English Journal, 103(5), 47-52.

Seelow, D. (2010). The graphic novel as advanced literacy tool. Journal of Media Literacy Education, 2(1), 57-64.

Serafini, F. (2015). Multimodal literacies: From theories to practices. Language Arts, 92(6), 412-422.

Shor, I. (1999). What is critical literacy? Journal of Pedagogy, Pluralism \& Practice, 1(4), 27.

Smetana, L., Odelson, D., Burns, H., \& Grisham, D. (2009). Using graphic novels in the high school classroom: Engaging deaf students in genre. Journal of Adolescent and Adult Literacy, 53(3), 228-240.

Spiegelman, A. (1980). Maus. New York, NY: Pantheon Books.

St. Denis, V. (2007). Aboriginal education and anti-racist education: Building alliances across cultural and racial identity. Canadian Journal of Education, 30(4), 10681092.

Stanton, C., \& Sutton, K. (2012). "I guess I do know a good story": Re-envisioning writing process with Native American students and communities. The English Journal, 102(2), 78-84.

Street, B. (2003). What's "new" in New Literacy Studies? Critical approaches to literacy in theory and practice. Current Issues in Comparative Education, 5(2).

Truth and Reconciliation Commission of Canada. (2015). Final Report of the Truth and Reconciliation Commission of Canada: Volume One: Summary: Honoring the Truth, Reconciling for the Future. Toronto, ON: James Lorimer \& Company. 
Vygotsky, L. (1989). Thought and language. Translated and edited by Alex Kozulin. Cambridge, MA: The MIT Press.

Wharf Higgins, J., \& Begoray, D. (2012). Exploring the borderlands between media and health: Conceptualizing 'critical media health literacy'. Journal of Media Literacy Education, 4(2), 136-148.

Wilmot, R., Begoray, D., \& Banister, E. (2013). Aboriginal students, critical media health literacy and the creation of a graphic novel health education tool. In Education, 19(2), 72-85.

Yahgulanaas, M. (2009). Red: A Haida manga. Vancouver, BC: Douglas McIntyre.

\section{Author Biographies}

Alexis Brown is a $\mathrm{PhD}$ candidate in the department of Curriculum and Instruction at the University of Victoria, with a focus on Language and Literacies. She is also a highschool Social Studies and English teacher, and has worked in urban, rural, and alternative classroom settings. Her research interests include critical literacies with Indigenous adolescents, dialogic pedagogy, and adolescent literacies.

Deborah Begoray is a Professor of Language and Literacies at the University of Victoria. Her main area of research is health literacies with culturally marginalized adolescent populations. She also works with pre-service and in-service teachers, and with health professionals in community-engaged research. In the Faculty of Education, she teaches courses in ELA methods, multimodal composition, qualitative research, curriculum studies and young adult literature. 